\title{
Assessment of exposure to Plasmodium falciparum transmission in a low endemicity area by using multiplex fluorescent microsphere-based serological assays
}

\author{
Jean Biram Sarr ${ }^{1,2^{*}}$, Eve Orlandi-Pradines ${ }^{4}$, Sonia Fortin ${ }^{2}$, Cheikh Sow ${ }^{2}$, Sylvie Cornelie ${ }^{1}$, François Rogerie ${ }^{2}$, \\ Soihibou Guindo ${ }^{2}$, Lassana Konate ${ }^{3}$, Thierry Fusai ${ }^{4}$, Gilles Riveau ${ }^{2}$, Christophe Rogier ${ }^{4,5}$ and Franck Remoue
}

\begin{abstract}
Background: The evaluation of malaria transmission intensity is a crucial indicator for estimating the burden of malarial disease. In this respect, entomological and parasitological methods present limitations, especially in low transmission areas. The present study used a sensitive multiplex assay to assess the exposure to Plasmodium falciparum infection in children living in an area of low endemicity. In three Senegalese villages, specific antibody (IgG) responses to 13 pre-erythrocytic P. falciparum peptides derived from Lsa1, Lsa3, Glurp, Salsa, Trap, Starp, Csp and Pf11.1 proteins were simultaneously evaluated before (June), at the peak (September) and after (December) the period of malaria transmission, in children aged from 1 to 8 years.

Results: Compared to other antigens, a high percentage of seropositivity and specific antibody levels were detected with Glurp, Salsa1, Lsa3NR2, and Lsa1J antigens. The seropositivity increased with age for all tested antigens. Specific lgG levels to Glurp, Salsa1, Lsa3NR2, and Lsa1J were significantly higher in P. falciparum infected children compared to non-infected and this increase is significantly correlated with parasite density.

Conclusion: The multiplex assay represents a useful technology for a serological assessment of rapid variations in malaria transmission intensity, especially in a context of low parasite rates. The use of such combined serological markers (i.e. Glurp, Lsa1, Lsa3, and Salsa) could offer the opportunity to examine these variations over time, and to evaluate the efficacy of integrated malaria control strategies.
\end{abstract}

\section{Background}

Plasmodium falciparum malaria is a major cause of human morbidity and mortality in sub-Saharan Africa, and its transmission varies greatly in endemicity across the continent [1]. The expanding utilization of combined malaria control strategies including insecticide impregnated bednets and artemisinin combination therapies, has contributed to greatly reduce malaria transmission in several sub-Saharan African areas [2,3]. Consequently, the current methods for evaluating malaria transmission intensity (MTI), such as entomological inoculation rate and Plasmodium parasitemia in

\footnotetext{
* Correspondence: jean-biram.sarr@ird.fr

'MIVEGEC (UM1-CNRS 5290-IRD 224), Montpellier, France

Full list of author information is available at the end of the article
}

human populations, present substantial limitations, e.g. reproducibility and can be time-consuming. In addition, both entomological and parasitological measures are affected by the seasonality and require a precise followup during longitudinal studies [4]. For this purpose, there is an increased need for developing new tools for the monitoring of MTI in more frequent contexts of low malaria transmission. In this respect, the sero-epidemiological approach offers a theoretical advantage over parasite prevalence for assessing MTI or changes in prevalence following the implementation of control programmes [5]. In order to identify Plasmodium infections, serological markers show greater sensitivity, as seroprevalence reflects cumulative exposure to infections and thus is less affected by the changes in parasite densities, which could be undetectable in the case of 
very low parasite density. Previous studies showed that serological measurements are robust to detect short term variations in transmission, and should be a pertinent tool for evaluating malaria exposure in the context of low transmission [6].

The Circumsporozoite protein (CSP: a protein expressed by sporozoites and early liver forms), has been frequently used for the serological estimation of MTI [7]. Controversial studies have reported that antibody $(\mathrm{Ab})$ responses directed to the repetitive NANP domains of CSP remained very low throughout the first year of life [8]. In addition, it has been suggested that human immunological memory following malaria infection is short-lived because $\mathrm{Ab}$ responses rapidly decline after the end of the transmission season or exposure period [9], and after treatment of a clinical episode [10]. It suggests that maintenance of immunological memory therefore requires antigen persistence and may be agedependent [11]. For this purpose, it has been then demonstrated that the simultaneous use of several antigens (Ags) as serological markers could lead to a better evaluation of malaria exposure than using only one Ag, i.e. CSP [12]. Human Ab levels to plasmodial Ags are classically assessed using the enzyme-linked immunosorbant assay (ELISA) test. This technique is labour-intensive and time-consuming, as well as requiring considerable quantity of Ags and sera samples. An immunoassay that measures Ab to multiple Ags simultaneously would be highly advantageous [13]. Multiplexed bead assays gives similar sensibility than ELISA assays, and have been developed in several studies for simultaneous detection of Ab against multiple plasmodial Ags in humans living in endemic areas [14,15].

In the present study, we used multiplex fluorescent microsphere-based assays measuring simultaneously human Ab to thirteen P. falciparum peptides [14] to assess malaria transmission in children living in a low endemicity area. All Ags used in the assay have previously been shown to be antigenic and associated with malaria transmission in individuals living in malaria endemic areas $[6,14]$.

\section{Materials and methods Study population}

The study was performed in the villages of Mboula (Ferlo area: $15^{\circ} 40^{\prime} \mathrm{N}, 15^{\circ} 25^{\prime} \mathrm{W}$ ), Gankette Balla (near the Guiers Lake: $15^{\circ} 58^{\prime} \mathrm{N}, 15^{\circ} 55^{\prime} \mathrm{W}$ ) and Mbilor (Low valley area: $16^{\circ} 29^{\prime} \mathrm{N}, 15^{\circ} 33^{\prime} \mathrm{W}$ ) in Northern Senegal, located along the Senegal Basin River [16]. This site is a dry savannah area, with approximately $400 \mathrm{~mm}$ of rain by year. Malaria transmission is low (average of 3 to 7 infective bites per human per year), markedly seasonal (occurring from July to October), with a peak in September [16].
Three cross-sectional surveys were performed in June, September and December 2004 in the three villages. For each passage, a sub-cohort of children aged from 1 to 8 years was randomly selected from an existing cohort of 450 children, as previously described [17]. A total of 186 children (Mboula $n=64$; Gankette $n=56$ and Mbilor $n$ $=66$, selected for the 3 passages) were included in the present study. For each child, parasitological measurements of malaria were performed at each passage using thick blood smears obtained by finger-prick. The smears were Giemsa stained to identify Plasmodium species and the number of malaria parasites was counted in 200 microscopic fields. Parasite density was defined as the number of $P$. falciparum parasites/ $\mu$ l of blood, corresponding to an average of 8000 leucocytes. In the same way, capillary blood was collected from each child at each passage for immunological assessments.

The present study followed ethical principles according to the Helsinki Declaration, and was approved by the Ethics Committee of the Ministry of Health of Senegal (CNRS, June 2004). Informed consent was obtained from the parents/tutors of the children.

\section{Multiplex bead-based assay}

The multiplex technique was performed using the same sequences of $P$. falciparum peptides (Lsa1-41, Lsa1J, Lsa3NR2, Lsa3RE, Glurp, Glurp.P3, Salsa1, Salsa2, Trap1, Trap2, StarpR, Csp, Sr11.1), and the procedure for coupling Ags to beads, as previously described [14]. Briefly, the P. falciparum peptides were synthesized with an added $\mathrm{N}$-terminal cysteine residue and covalently coupled with bovine serum albumin by Genepep (Ales, France). These Ags were coupled to beads (Biorad Inc, CA, USA) and $50 \mu \mathrm{l} /$ well was deposited at the final concentration of 80 beads/ $\mu$ l per peptide. Diluted individual sera $(1 / 100)$ in equal volumes of PBS and MFIA (Multiplex Fluorescence ImmunoAssay) diluents (Charles River Laboratories Inc, MA, USA) were added in duplicate using $50 \mu \mathrm{l} /$ well. The Luminex system was set for reading a minimum of 100 beads per spectral address, and results were expressed as $\triangle \mathrm{MFI}$ "median fluorescent intensity" value with $\triangle \mathrm{MFI}=\mathrm{MFI}_{\mathrm{Ag}}-\mathrm{MFI}_{\mathrm{BSA}}$, where $\mathrm{MFI}_{\mathrm{Ag}}$ represents the mean of individual MFI value for beads coupled with $P$. falciparum Ag, and $\mathrm{MFI}_{\mathrm{BSA}}$ the individual MFI value for each serum for beads without coupled Ag. For calculating the seropositivity threshold, the means and standard deviations (SD) of $\triangle$ MFI of individuals living permanently in a non-endemic area ( $i$. $e$. negative control group $-\mathrm{n}=19$ ) were estimated for each Ag. The lower limit of positivity of $\mathrm{Ab}$ responses to one Ag was estimated as the mean of $\triangle \mathrm{MFI}$ of the negative control group $+3.09 \mathrm{SD}$. Therefore, values higher than the cut-offs should be observed in less than $1 \%$ of sera of non-exposed individuals under the 
hypothesis of normally distributed of $\triangle$ MFI. The thresholds of positivity were $7466.6,684.0,725.0,225.0,344.2$, $4593.1,424.8,439.7,435.2,933.6,452.6,380.2$, and 302.5 respectively for Lsa1-41, Lsa1J, Lsa3NR2, Lsa3RE, Glurp, Glurp.P3, Salsa1, Salsa2, Trap1, Trap2, StarpR, $\mathrm{Csp}$, and SR11.1. Individual time-period variations in $\mathrm{Ab}$ levels for each Ag were assessed by the ratio of $\triangle \mathrm{MFI}$ values collected at different time intervals, i.e. between June - September; September - December or June - September. The significant increase in Ab level to each Ag was defined as a value superior to the mean +3.09 SD of the ratio in $\triangle \mathrm{MFI}$ in the negative control group collected two times at four months interval.

\section{Statistical analysis}

All data were analyzed with Graph Pad Prism ${ }^{\circledR}$ (Graph Pad, San Diego, USA) version 4. After checking for normal distribution, the proportions of Ab-positive individuals and Ab levels were analyzed using the chi-squared test, Mann-Whitney U-test, Kruskal-Wallis test, where appropriate. Spearman's correlation was used to check for correlations between continuous variables. Differences were considered significant at $\mathrm{P}<0.05$.

\section{Results and discussion}

The proportion of seropositive and the level of specific Ab (IgG) responses directed to different P. falciparum peptides are presented for all studied individuals (Figure 1). A high IgG level was found in the majority of peptides tested. Lsa1-41 presented the highest Ab responses, i.e. antigenicity, with a $\triangle$ MFI mean of 7673 (95\% CI $=7010$ - 8336). Some other pre-erythrocytic (GlurpP3, Salsa1, Glurp, Lsa3NR2, Trap2 and Lsa1J) peptides were associated with moderate $\mathrm{Ab}$ response levels with a $\triangle$ MFI values ranging from 665 (95\% CI = 473.9 - 857.1) to $3000(95 \% \mathrm{CI}=2890$ - 3265). In contrast, StarpR, Csp, Trap1, Salsa2, Sr11.1 and Lsa3RE peptides presented lower levels of antigenicity. The proportion of seropositive was markedly higher for the Glurp peptide. Moderate seroprevalence was observed for Salsa1, Lsa1-41, Starp, Lsa3NR2, and Lsa1J peptides, whereas a very low proportion of seropositive was observed for all other Ags. These results suggested that pre-erythrocytic Lsa1-41, Salsa1, Glurp, Lsa1J and Lsa3NR2 peptides appeared to be most antigenic, giving the highest proportion of seropositive, and therefore could be potential serological markers of malaria transmission. However, it can not be excluded that differences in antigenicity levels ( $\triangle$ MFI values) between these peptides could be due also to the different structure of repetitive epitopes and to their conformation when they are coupled to the beads, as previously indicated [18]. Furthermore, the specific $\mathrm{Ab}$ response levels and the seropositivity (Table 1 ) to these relevant antigens (Lsa141, Salsa1, Glurp, Lsa1J and Lsa3NR2) were investigated according to the village and period of malaria transmission. No statistical influence of village and of time-period on specific Ab level (data not shown) and seropositivy were observed. These results could be attributed to the similar prevalence of P. falciparum in

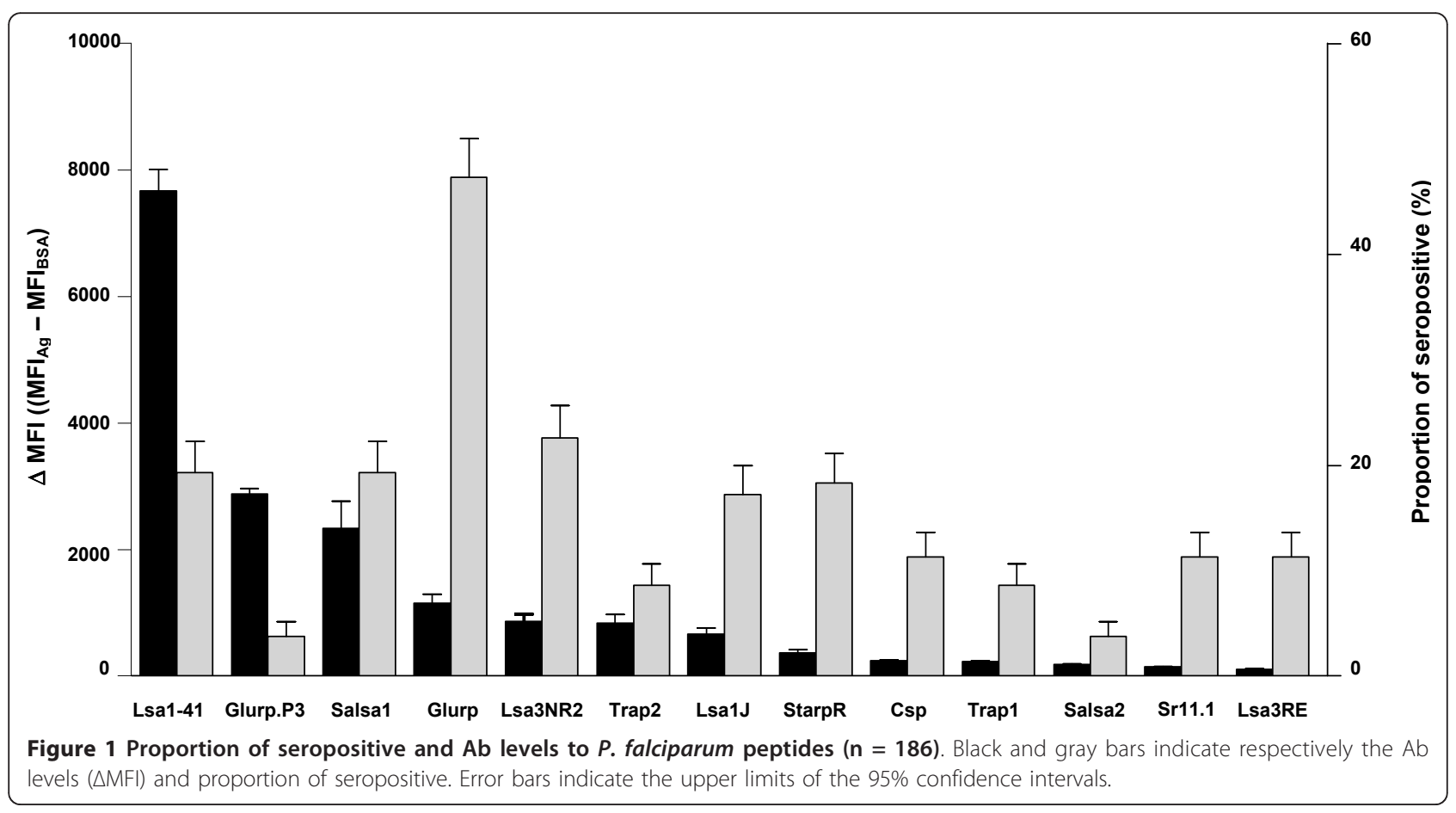


Table 1 Proportion and number of seropositive according to the period of malaria transmission and village.

\begin{tabular}{|c|c|c|c|c|c|c|c|c|c|c|c|c|}
\hline & \multicolumn{3}{|c|}{ Mboula $(n=64)$} & \multicolumn{3}{|c|}{ Gankette $(n=56)$} & \multicolumn{3}{|c|}{ Mbilor $(n=66)$} & \multicolumn{3}{|c|}{ All villages $(n=186)$} \\
\hline & June & Sept & Dec & June & Sept & Dec & June & Sept & Dec & June & Sept & Dec \\
\hline Lsa1-41 & $\begin{array}{c}6.7 \% \\
(1 / 15)\end{array}$ & $\begin{array}{l}18.2 \% \\
(4 / 22)\end{array}$ & $\begin{array}{l}25.9 \% \\
(7 / 27)\end{array}$ & $\begin{array}{l}22.2 \% \\
(4 / 18)\end{array}$ & $\begin{array}{l}26.3 \% \\
(5 / 19)\end{array}$ & $\begin{array}{l}36.8 \% \\
(7 / 19)\end{array}$ & $\begin{array}{l}7.7 \% \\
(2 / 26)\end{array}$ & $\begin{array}{l}14.3 \% \\
(3 / 21)\end{array}$ & $\begin{array}{l}15.8 \% \\
(3 / 19)\end{array}$ & $\begin{array}{l}11.9 \% \\
(7 / 59)\end{array}$ & $\begin{array}{c}19.3 \% \\
(12 / 62)\end{array}$ & $\begin{array}{c}26.1 \% \\
(17 / 65)\end{array}$ \\
\hline Salsa1 & $\begin{array}{l}26.7 \% \\
(4 / 15)\end{array}$ & $\begin{array}{c}9.1 \% \\
(2 / 22)\end{array}$ & $\begin{array}{l}22.2 \% \\
(6 / 27)\end{array}$ & $\begin{array}{l}22.2 \% \\
(4 / 18)\end{array}$ & $\begin{array}{l}15.8 \% \\
(3 / 19)\end{array}$ & $\begin{array}{l}15.8 \% \\
(3 / 19)\end{array}$ & $\begin{array}{l}23.1 \% \\
(6 / 26)\end{array}$ & $\begin{array}{l}23.8 \% \\
(5 / 21)\end{array}$ & $\begin{array}{l}15.8 \% \\
(3 / 19)\end{array}$ & $\begin{array}{c}23.7 \% \\
(14 / 59)\end{array}$ & $\begin{array}{c}16.1 \% \\
(10 / 62)\end{array}$ & $\begin{array}{c}18.5 \% \\
(12 / 65)\end{array}$ \\
\hline Glurp & $\begin{array}{l}46.7 \% \\
(7 / 15)\end{array}$ & $\begin{array}{l}31.8 \% \\
(7 / 22)\end{array}$ & $\begin{array}{c}48.1 \% \\
(13 / 27)\end{array}$ & $\begin{array}{l}44.4 \% \\
(8 / 18)\end{array}$ & $\begin{array}{l}42.1 \% \\
(8 / 19)\end{array}$ & $\begin{array}{l}31.6 \% \\
(6 / 19)\end{array}$ & $\begin{array}{c}61.5 \% \\
(16 / 26)\end{array}$ & $\begin{array}{c}47.6 \% \\
(10 / 21)\end{array}$ & $\begin{array}{c}68.4 \% \\
(13 / 19)\end{array}$ & $\begin{array}{c}52.5 \% \\
(31 / 59)\end{array}$ & $\begin{array}{c}40.3 \% \\
(25 / 62)\end{array}$ & $\begin{array}{c}49.2 \% \\
(32 / 65)\end{array}$ \\
\hline Lsa1J & $\begin{array}{l}33.3 \% \\
(5 / 15)\end{array}$ & $\begin{array}{l}31.8 \% \\
(7 / 22)\end{array}$ & $\begin{array}{l}29.6 \% \\
(8 / 27)\end{array}$ & $\begin{array}{l}16.7 \% \\
(3 / 18)\end{array}$ & $\begin{array}{l}15.8 \% \\
(3 / 19)\end{array}$ & $\begin{array}{l}21.0 \% \\
(4 / 19)\end{array}$ & $\begin{array}{c}7.7 \% \\
(2 / 26)\end{array}$ & $\begin{array}{c}4.8 \% \\
(1 / 21)\end{array}$ & $\begin{array}{c}5.3 \% \\
(1 / 19)\end{array}$ & $\begin{array}{c}16.9 \% \\
(10 / 59)\end{array}$ & $\begin{array}{c}17.7 \% \\
(11 / 62)\end{array}$ & $\begin{array}{c}20.0 \% \\
(13 / 65)\end{array}$ \\
\hline Lsa3NR2 & $\begin{array}{c}6.7 \% \\
(1 / 15)\end{array}$ & $\begin{array}{c}9.1 \% \\
(2 / 22)\end{array}$ & $\begin{array}{l}25.9 \% \\
(7 / 27)\end{array}$ & $\begin{array}{l}27.8 \% \\
(5 / 18)\end{array}$ & $\begin{array}{l}31.6 \% \\
(6 / 19)\end{array}$ & $\begin{array}{l}36.8 \% \\
(7 / 19)\end{array}$ & $\begin{array}{l}11.5 \% \\
(3 / 26)\end{array}$ & $\begin{array}{l}38.1 \% \\
(8 / 21)\end{array}$ & $\begin{array}{l}10.5 \% \\
(2 / 19)\end{array}$ & $\begin{array}{l}15.2 \% \\
(9 / 59)\end{array}$ & $\begin{array}{c}25.8 \% \\
(16 / 62)\end{array}$ & $\begin{array}{c}24.6 \% \\
(16 / 65)\end{array}$ \\
\hline
\end{tabular}

The prevalence rate of positive P. falciparum infection was $37.3 \%, 40.3 \%, 43.1 \%$ respectively at June, September, December and $45.3 \%$, $41.1 \%$ and $34.9 \%$ respectively in Mboula, Gankette and Mbilor villages.

children in June $(37.3 \%, \mathrm{n}=22)$, September $(40.3 \%, \mathrm{n}=$ $25)$ and December $(43.1 \%, \mathrm{n}=28)$ and according to the village (Mboula 45.3\%, $\mathrm{n}=29$; Gankette 41.1\%, $\mathrm{n}=23$; Mbilor 34.9\%, $\mathrm{n}=23$ ).

In the objective to explore the possibility that these potential serological markers could reflect exposure to malaria over a prolonged period, the proportion of seropositive to at least one peptide, and the number of peptides that showed seropositivity in children were analyzed according to age (Figure 2). The seropositivity to at least one peptide increased significantly according to age group, and remained higher in older ( $>5$ years) than in younger $(\leq 5$ years $)$ children $(\mathrm{P}<0.001)$. The number of peptides for which children developed high IgG titers was significantly age-dependant $(\mathrm{P}<0.001)$. Lsa1-41, Salsa1, Glurp, Lsa3NR2, Trap2, Csp, Trap1, Salsa2 and StarpR peptides showed a significant increase of seropositivity with age (all $\mathrm{P}<0.02)$. In addition, in older children (7-8 years) who were seropositive to at least one peptide, $93.0 \%$ (40 of 43) were seropositive to at least one of 4 specific peptides: Lsa141, Salsa1, Glurp and Lsa3NR2. These results suggested that seropositivy to peptide reflects cumulative exposure to malaria infection, and that it could need

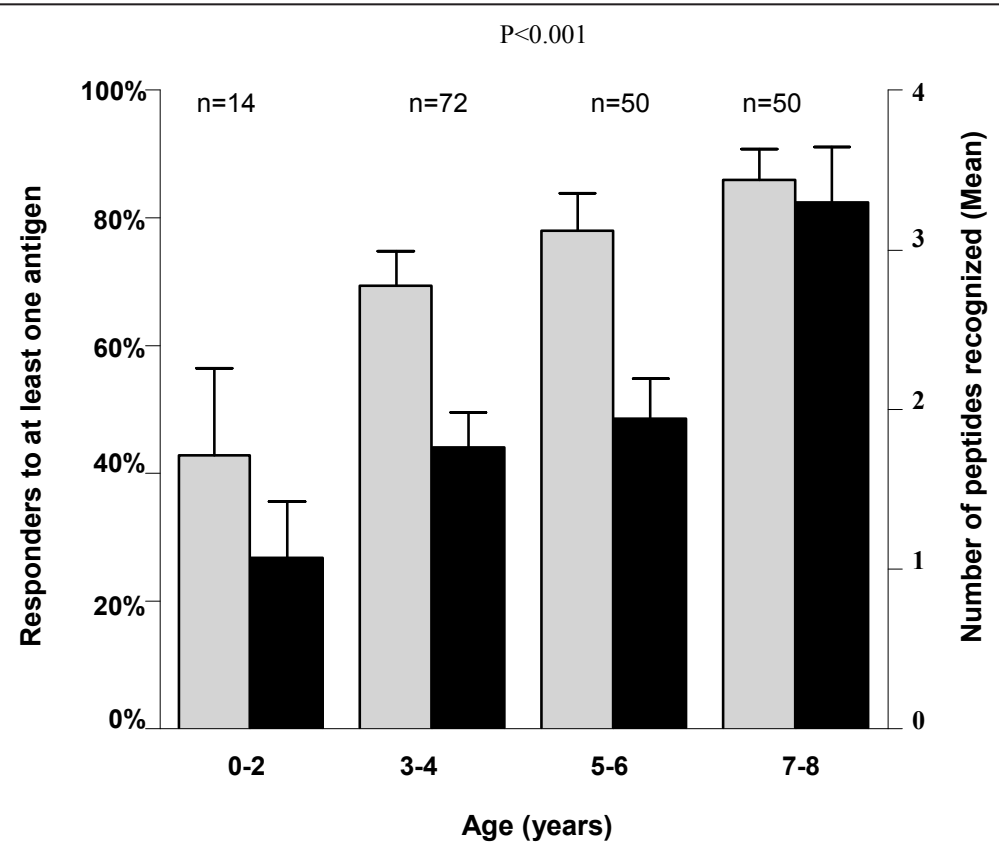

Figure 2 Number of $P$. falciparum peptides that produced seropositive results and proportion of seropositive to at least one peptide, according to the age. Gray and black bars indicate respectively the proportion of responders to at least one peptide and the mean number of peptides that showed seropositive results. Error bars indicate the upper limits of the $95 \%$ confidence intervals. $P$ value of the Kruskal-Wallis test. 
more than one peptide for assessing MTI. The need to use several peptides for pertinent MTI evaluation appeared relevant especially in young children $(<5$ years), as previously described [19].

The incidence rate of a significant increase in $\operatorname{IgG}$ level to $P$. falciparum peptides is shown according to the 3 time-periods, i.e. between June - September (Figure 3A); September - December (Figure 3B) and June December 2004 (Figure 3C). Significant increase of specific IgG levels to at least one peptide was observed for $33.3 \%$ (95\% CI $=17.2-49.5 \%$ ), $45.7 \%$ (95\% CI $=28.3$ -
$63.1 \%)$ and $51.3 \%$ (95\% CI $=34.4-68.2 \%)$ of individuals, between June-September; September-December and June-December, respectively. In particular, IgG levels to Glurp, Lsa1J, Salsa1, Csp, and Lsa3NR2 increased significantly whatever the time-period studied. In contrast, no increase in Ab was observed for Lsa3RE, Salsa2, Sr11.1, Glurp.P3 and Trap1 (data not shown). Among the 47 individuals presenting a significant increase of $\mathrm{Ab}$ to at least one peptide between the different periods, 25 (53.2\%), 16 (34.0\%), 15 (31.9\%), 6 (12.8\%), 6 (12.8\%), 5 (10.6\%) showed an increased IgG to Glurp, Lsa1J,

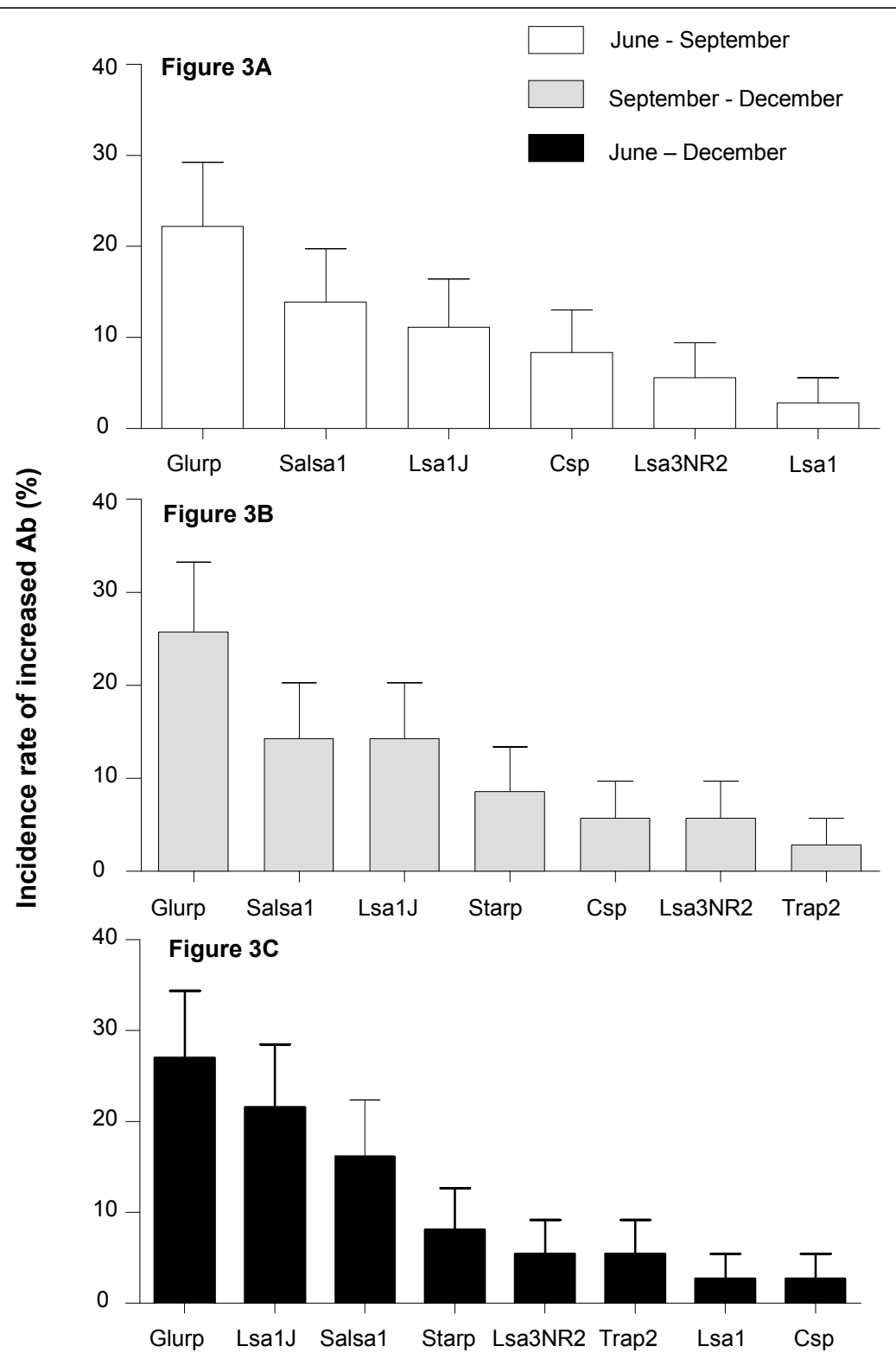

Figure 3 Incidence of significant increases in specific Ab to P. falciparum peptides (Glurp, Salsa1, Lsa1J, Starp, Csp, Lsa3NR2, Lsa1, and Trap2) between June - September (Figure 3A, $n=33$ ); September - December (Figure 3B, $n=32$ ) and June - December 2004 (Figure $\mathbf{3 C}, \mathbf{n}=\mathbf{3 3}$ ). For all other peptides, no significant increase in Ab was observed during the period of malaria transmission. Error bars indicate the upper limits of the $95 \%$ confidence intervals. 
Salsa1, Starp, Lsa3NR2 and Csp respectively. Moreover, the incidence rate of increased IgG levels to Glurp, Salsa1 and Lsa1J, were significantly higher compared to others peptides (all $\mathrm{P}<0.02$ ), and then, whatever the periods of malaria transmission considered. Altogether, these results suggested that Glurp, Salsa1, Lsa1J, Lsa3NR2 and Csp peptides could be the relevant candidates for evaluating potential season-dependent variations of malaria exposure. In addition, the increase of the number of Ags tested may provide a better estimation of malaria transmission, particularly in areas of low endemicity.

Specific Ab levels to P. falciparum peptides were compared according to the presence of malaria infection in children (Figure 4). Positive children for P. falciparum $(n=75)$, presented higher specific Ab response to Glurp, Salsa1, Lsa3NR2, and Lsa1J peptides (all $P<$ $0.05)$ than negative children $(\mathrm{n}=111)$. In $P$. falciparum infected children, $80.0 \%, 54.7 \%, 62.7 \%$, and $50.7 \%$ were seropositive to Glurp, Lsa3NR2, Salsa1 and Lsa1J respectively. Moreover, $85.3 \%$ of $P$. falciparum infected children were seropositive for at least one of the candidate antigens (Glurp, Lsa3NR2, Salsa1, and Lsa1J). For other peptides, no significant differences of Ab response levels were observed between $P$. falciparum positive and negative children (data not shown). Moreover, the highest differences in specific IgG levels were respectively observed for Glurp, Salsa1, Lsa3NR2 and Lsa1J. The statistical correlation between specific IgG level and the $P$. falciparum parasite density indicated a positive and significant correlation for Glurp, Salsa1, Lsa3NR2, and Lsa1J (all $r>0.320$, all $P<0.01$ ). Altogether, these data suggested that Glurp, Salsa1, Lsa3NR2 and Lsa1J peptides seem to be closely associated with P. falciparum parasite presence and intensity, and could be therefore potential serological markers of malaria exposure. This positive association between $P$. falciparum infection and specific $\mathrm{Ab}$ response against plasmodial antigens is a consistent observation, and could result from a booster effect of sustained parasite-exposure [6,20-22].

Some of these antigens (Glurp, Lsa1J, Lsa3NR2, and Salsa1) appeared to satisfy several of the requirements expected for a relevant marker of MTI. These peptides are antigenic and provided a higher incidence rate of significant increases in IgG levels. Specific Ab levels to these Ags are closely associated with the presence and the intensity of malaria infection. Moreover, in children seropositive to at least one peptide, $86.3 \%$ (120 of 139) were seropositive to at least one out of these four peptides. Pre-erythrocytic Glurp, Lsa1, Lsa3 and Salsa Ags are mainly expressed in infected human hepatocytes, they present little polymorphism from geographically different $P$. falciparum isolates [23-26]. Recent immunoepidemiological studies in different endemic areas, have shown a positive association of specific $\mathrm{Ab}$ directed to these Ags and the level of malaria transmission [14]. Our results strengthen that pre-erythrocyte Ags, and particularly Glurp, Lsa1, Lsa3, and Salsa, could be

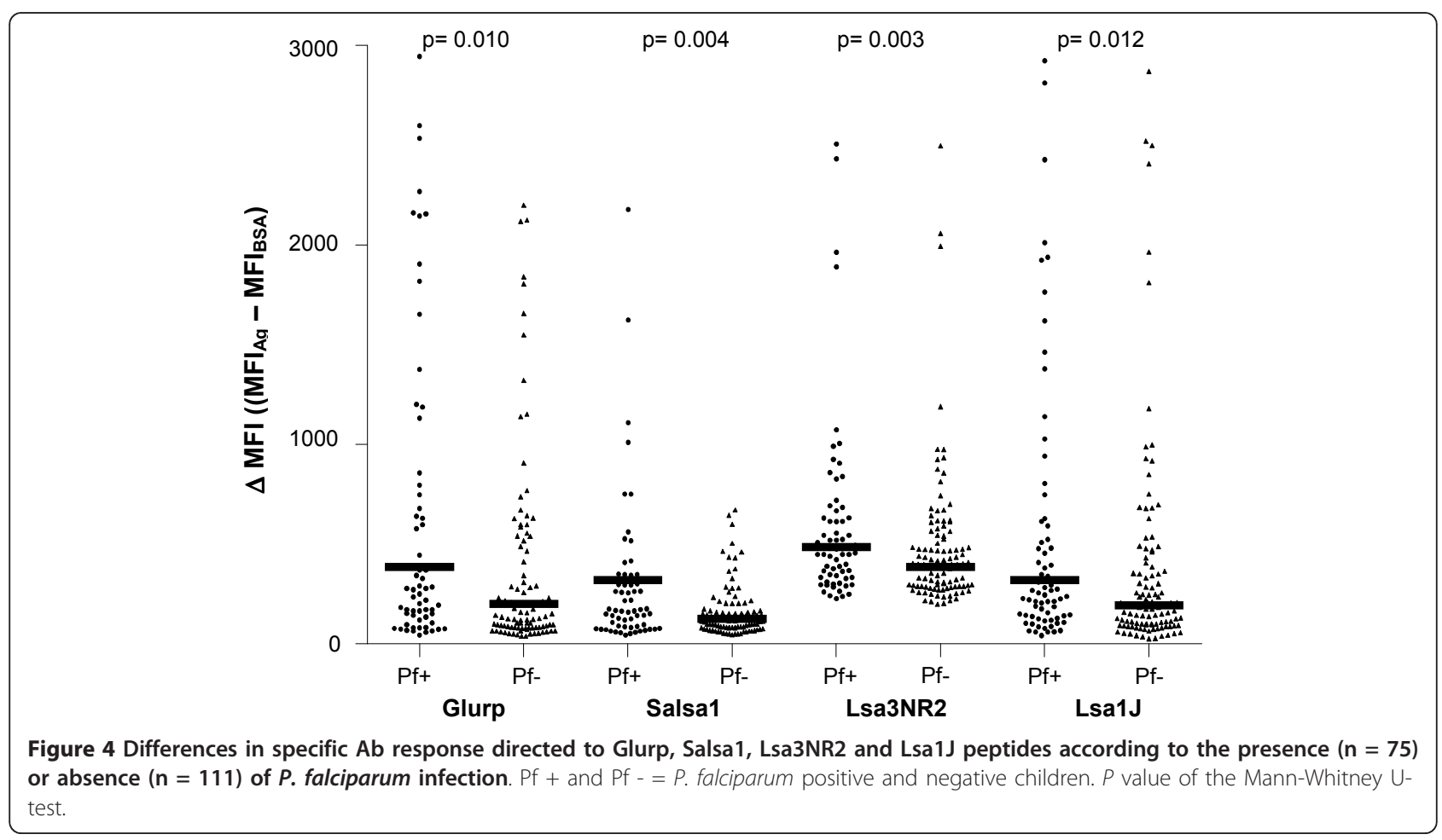


pertinent markers to assess and to survey malaria transmission, at the individual level and in the context of low P. falciparum prevalence. Nevertheless, further studies will be valuable for validating these potential serological markers. These studies could include future modelling exercises including covariates factors such as age, genetic background, village of residence, impact of vector/parasite control programmes and the period of transmission. This kind of tool could allow elaborating a precise picture of malaria epidemiology in large-scale areas, or be used as a complementary indicator for evaluating the efficacy of integrated malaria control strategies.

\section{Conclusion}

In conclusion, the multiplex assay provides a useful tool to simultaneously measured $\mathrm{Ab}$ responses directed to several Ags used as potential markers of malaria transmission. In low transmission areas, serological measurements to various malaria antigens are needed for estimating short term and small scale variations in MTI. However, the present study suggests that the combined assessment of Ab levels to only Glurp, Lsa1, Lsa3, and Salsa Ags could be a pertinent serological marker for evaluating the MTI.

\section{Acknowledgements}

The authors gratefully acknowledge the populations of Mboula, Mbilor and Gankette, and all the health care agents of these three villages for their participation in the study. The PAL-Fleuve programme was supported by the EPLS GNO, the Délégation Générale pour l'Armement (DGA-CO0co406 "Salivaplus" and 03co009-05 "Impact-Vector"), the French Ministry of Research (PAL+ program) and the Research Institute for Development. The authors thank the FSD "Fonds Social de Développement", from the Embassy of France in Senegal for their financial participation.

\section{Author details}

${ }^{1}$ MIVEGEC (UM1-CNRS 5290-IRD 224), Montpellier, France. ${ }^{2}$ ONG Espoir Pour La Santé (EPLS), Saint-Louis, Senegal. ${ }^{3}$ Laboratoire d'Ecologie Vectorielle et Parasitaire (LEVP), UCAD, Dakar, Senegal. ${ }^{4}$ IRBA \& UMR6236, Marseille, France. ${ }^{5}$ Institut Pasteur de Madagascar, Antananarivo, Madagascar.

\section{Authors' contributions}

All authors read and approved the final manuscript.

JBS carried out the immunological assessments, statistical analysis, interpretation of data and drafted the manuscript. CS, SF, SG contributed to field activities, microscopic examinations, and initial statistical analysis. SC helped to draft the manuscript. EO-P, FR1, LK, TF and CR contributed to the design of the study, and choice of the peptides. GR, CR, FR2 provided the scientific supervision, contributed to the design of the methods, interpretation of the data, and revised the manuscript.

\section{Competing interests}

The authors declare that they have no competing interests.

Received: 20 July 2011 Accepted: 7 November 2011

Published: 7 November 2011

\section{References}

1. Snow RW, Omumbo JA, Lowe B, Molyneux CS, Obiero JO, Palmer A Weber MW, Pinder M, Nahlen B, Obonyo C, et al: Relation between severe malaria morbidity in children and level of Plasmodium falciparum transmission in Africa. Lancet 1997, 349:1650-1654.

2. Guerra CA, Hay SI, Lucioparedes LS, Gikandi PW, Tatem AJ, Noor AM, Snow RW: Assembling a global database of malaria parasite prevalence for the Malaria Atlas Project. Malar J 2007, 6:17.

3. O'Meara WP, Bejon P, Mwangi TW, Okiro EA, Peshu N, Snow RW, Newton CR, Marsh K: Effect of a fall in malaria transmission on morbidity and mortality in Kilifi, Kenya. Lancet 2008, 372:1555-1562.

4. Kelly-Hope LA, McKenzie FE: The multiplicity of malaria transmission: a review of entomological inoculation rate measurements and methods across sub-Saharan Africa. Malar J 2009, 8:19.

5. Drakeley C, Cook J: Chapter 5. Potential contribution of seroepidemiological analysis for monitoring malaria control and elimination: historical and current perspectives. Adv Parasitol 2009, 69:299-352.

6. Orlandi-Pradines E, Penhoat K, Durand C, Pons C, Bay C, Pradines B, Fusai T, Josse R, Dubrous P, Meynard JB, et al: Antibody responses to several malaria pre-erythrocytic antigens as a marker of malaria exposure among travelers. Am J Trop Med Hyg 2006, 74:979-985.

7. Webster HK, Gingrich JB, Wongsrichanalai C, Tulyayon S, Suvarnamani A, Sookto P, Permpanich B: Circumsporozoite antibody as a serologic marker of Plasmodium falciparum transmission. Am J Trop Med Hyg 1992, 47:489-497.

8. Kitua AY, Urassa H, Wechsler M, Smith T, Vounatsou P, Weiss NA, Alonso PL, Tanner M: Antibodies against Plasmodium falciparum vaccine candidates in infants in an area of intense and perennial transmission: relationships with clinical malaria and with entomological inoculation rates. Parasite Immunol 1999, 21:307-317.

9. Langhorne J, Ndungu FM, Sponaas AM, Marsh K: Immunity to malaria: more questions than answers. Nat Immunol 2008, 9:725-732.

10. Kinyanjui SM, Conway DJ, Lanar DE, Marsh K: IgG antibody responses to Plasmodium falciparum merozoite antigens in Kenyan children have a short half-life. Malar J 2007, 6:82.

11. Achtman AH, Bull PC, Stephens R, Langhorne J: Longevity of the immune response and memory to blood-stage malaria infection. Curr Top Microbiol Immunol 2005, 297:71-102.

12. Campo JJ, Whitman TJ, Freilich D, Burgess TH, Martin GJ, Doolan DL: Toward a Surrogate Marker of Malaria Exposure: Modeling Longitudinal Antibody Measurements under Outbreak Conditions. PLoS One 2011, 6: e21826.

13. Fouda GG, Leke RF, Long C, Druilhe P, Zhou A, Taylor DW, Johnson AH: Multiplex assay for simultaneous measurement of antibodies to multiple Plasmodium falciparum antigens. Clin Vaccine Immunol 2006, 13:1307-1313.

14. Ambrosino E, Dumoulin C, Orlandi-Pradines E, Remoue F, Toure-Balde A Tall A, Sarr JB, Poinsignon A, Sokhna C, Puget K, et al: A multiplex assay for the simultaneous detection of antibodies against 15 Plasmodium falciparum and Anopheles gambiae saliva antigens. Malar J 2010, 9:317.

15. Elshal MF, McCoy JP: Multiplex bead array assays: performance evaluation and comparison of sensitivity to ELISA. Methods 2006, 38:317-323.

16. Dia I, Konate L, Samb B, Sarr JB, Diop A, Rogerie F, Faye M, Riveau G, Remoue F, Diallo M, Fontenille D: Bionomics of malaria vectors and relationship with malaria transmission and epidemiology in three physiographic zones in the Senegal River Basin. Acta Trop 2008, 105:145-153.

17. Sarr JB, Remoue F, Samb B, Dia I, Guindo S, Sow C, Maiga S, Tine S, Thiam C, Schacht AM, et al: Evaluation of antibody response to Plasmodium falciparum in children according to exposure of Anopheles gambiae or Anopheles funestus vectors. Malar J 2007, 6:117.

18. Zerpa NC, Wide A, Noda J, Bermudez H, Pabon R, Noya OO: Immunogenicity of synthetic peptides derived from Plasmodium falciparum proteins. Exp Parasitol 2006, 113:227-234.

19. Stewart L, Gosling R, Griffin J, Gesase S, Campo J, Hashim R, Masika P, Mosha J, Bousema T, Shekalaghe S, et al: Rapid assessment of malaria transmission using age-specific sero-conversion rates. PLoS One 2009, 4: e6083.

20. Lee HW, Moon SU, Ryu HS, Kim YJ, Cho SH, Chung GT, Lin K, Na BK Kong Y, Chung KS, Kim TS: Usefulness of the recombinant liver stage antigen-3 for an early serodiagnosis of Plasmodium falciparum infection. Korean J Parasitol 2006, 44:49-54.

21. Migot-Nabias F, Deloron P, Ringwald P, Dubois B, Mayombo J, Minh TN, Fievet $N$, Millet $P$, Luty $A$ : Immune response to Plasmodium falciparum liver stage antigen-1: geographical variations within Central Africa and 
their relationship with protection from clinical malaria. Trans $R$ Soc Trop Med Hyg 2000, 94:557-562.

22. Nebie I, Tiono AB, Diallo DA, Samandoulougou S, Diarra A, Konate AT, Cuzin-Ouattara N, Theisen M, Corradin G, Cousens S, et al: Do antibody responses to malaria vaccine candidates influenced by the level of malaria transmission protect from malaria? Trop Med Int Health 2008, 13:229-237.

23. Bottius E, BenMohamed L, Brahimi K, Gras H, Lepers JP, Raharimalala L, Aikawa M, Meis J, Slierendregt B, Tartar A, et al: A novel Plasmodium falciparum sporozoite and liver stage antigen (SALSA) defines major B, T helper, and CTL epitopes. J Immunol 1996, 156:2874-2884.

24. Fidock DA, Gras-Masse H, Lepers JP, Brahimi K, Benmohamed L, Mellouk S, Guerin-Marchand C, Londono A, Raharimalala L, Meis JF, et al: Plasmodium falciparum liver stage antigen-1 is well conserved and contains potent B and T cell determinants. J Immunol 1994, 153:190-204.

25. Perlaza BL, Sauzet JP, Balde AT, Brahimi K, Tall A, Corradin G, Druilhe P: Long synthetic peptides encompassing the Plasmodium falciparum LSA3 are the target of human B and T cells and are potent inducers of B helper, T helper and cytolytic T cell responses in mice. Eur J Immunol 2001, 31:2200-2209.

26. Theisen M, Vuust J, Gottschau A, Jepsen S, Hogh B: Antigenicity and immunogenicity of recombinant glutamate-rich protein of Plasmodium falciparum expressed in Escherichia coli. Clin Diagn Lab Immunol 1995, 2:30-34.

doi:10.1186/1756-3305-4-212

Cite this article as: Sarr et al:: Assessment of exposure to Plasmodium falciparum transmission in a low endemicity area by using multiplex fluorescent microsphere-based serological assays. Parasites \& Vectors $20114: 212$

\section{Submit your next manuscript to BioMed Central and take full advantage of:}

- Convenient online submission

- Thorough peer review

- No space constraints or color figure charges

- Immediate publication on acceptance

- Inclusion in PubMed, CAS, Scopus and Google Scholar

- Research which is freely available for redistribution

Submit your manuscript at www.biomedcentral.com/submit 